\title{
Research on the Construction Path of New Agricultural Science in Local Agriculture and Forestry Universities and Colleges
}

\author{
Rui Chen ${ }^{1}$, Mengting Li $^{2}$, Jianhui Yun ${ }^{3, *}$ \\ ${ }^{1}$ Faculty of Economics and Management, Yunnan Agricultural University, Kunming, China \\ ${ }^{2}$ School of Foreign Languages, Yunnan Agricultural University, Kunming, China \\ ${ }^{3}$ Science and Technology Department, Yunnan Agricultural University, Kunming, China \\ *Corresponding author. Email: 36540822@qq.com
}

\begin{abstract}
The construction of New Agricultural Sciences is an important support for the implementation of rural revitalization strategy. Starting from the background of the construction of New Agricultural Sciences, this paper analyzes the new requirements of New Agricultural Sciences to local agriculture and forestry universities and colleges. Based on the analysis of the difficulties faced by the construction of New Agricultural Sciences in local agriculture and forestry universities and colleges, this paper put forward that the universities and colleges should implement the general requirements of establishing morality and cultivating agricultural talents who "understand agriculture, love agriculture, and love peasants" in the construction of New Agricultural Sciences. Colleges should actively plan the new agricultural specialty and reconstruct the discipline system of the new agricultural specialty. It is necessary to optimize teaching resources, improve practical teaching methods and decouple organizational structure, and reform the existing organizational structure system of universities and colleges.

Keywords: Local agriculture and forestry universities and colleges, construction of New Agricultural
\end{abstract}

Sciences, construction of the path

\section{THE BACKGROUND OF THE CONSTRUCTION OF NEW AGRICULTURAL SCIENCES}

\footnotetext{
"Issues relating to agriculture, rural areas and rural people" are important issues related to our country's national economy and people's livelihood, so the party and the state attach great importance to these issues and have issued a series of policies to support agriculture and rural development. Under the new situation and new requirements of our country's agriculture and rural development, our country's local agriculture and forestry universities and colleges shoulder the critical mission to cultivate agriculture and rural development professionals, while facing new opportunities and severe challenges. In November 2018, the Ministry of Education proposed to establish new engineering education, new medical education, new agricultural sciences and new liberal arts education with Chinese characteristics. In June 2019, the secretaries, principals and expert representatives, from more than 50 agriculture-related universities and colleges across the country, gathered in Yucun, Anji, Zhejiang, and issued the "ANJI Consensus---Declaration on the development of Emerging Agricultural Education in China". It is proposed that the construction of "new agricultural
}

science" is to transform and upgrade the existing agricultural majors with modern science and technology, and it is necessary to design and set up new agriculturerelated specialty that meet the needs of the development of new industries and new business forms and promote the reform of the curriculum system, practical teaching, and collaborative education to provide strong talent support for rural revitalization, centering on the strategy of rural revitalization and the construction of ecological civilization[1]. "ANJI Consensus---Declaration on the development of Emerging Agricultural Education in China" officially launched the construction of our country's new agricultural sciences. Agriculture and forestry universities and colleges must change their ideas, and reform the traditional agricultural discipline system, professional system and talent training system, to build a new era of higher agricultural education system. Local agriculture and forestry universities and colleges should focus on the national strategy and the needs of regional agriculture and rural development, exert their own characteristics and advantages, and rationally design and set up for new agricultural specialty to promote the professional reform and development of the school. 


\section{THE NEW REQUIREMENTS OF NEW AGRICULTURAL SCIENCES FOR AGRICULTURE AND FORESTRY COLLEGES}

The "new" of the new agricultural science is embodied in the transformation of the existing traditional agricultural sciences in agriculture and forestry universities and colleges. First, new agricultural science requires all agriculture and forestry universities and colleges to reconstruct the knowledge system, specialty and discipline system of new agricultural science. In order to compatible with the realities and meet the future demand of "issues relating to agriculture, rural areas and rural people" and meet the solution of the problems of "issues relating to agriculture, rural areas and rural people" in our country, agriculture and forestry universities and colleges need to reconstruct the knowledge system of new agricultural science and integrate new modern technologies(such as modern biotechnology, quantum information technology, and artificial intelligence) into the new agricultural knowledge system, and at the same time, humanistic knowledge(such as economics, management, and modern agriculture and rural development) should also be included. In recent years, with the rapid development of economy society, interdisciplinary and emerging industries are continually raising, so the traditional disciplines and majors(such as agriculture and forestry) in agriculture and forestry universities and colleges have gradually developed many research directions, and each research direction has gradually formed its own system and then formed its separate majors. The agriculture and forestry majors have been refined and differentiated into many new majors. The construction of new agricultural sciences requires all agriculture and forestry universities and colleges focus on the actual demand of agriculture and rural development, set foots in their position, make the best use of their advantages, and set up cross-professional and cross-field majors to reconstruct their professional discipline system. The second is that the new agricultural science requires all agriculture and forestry universities and colleges to reconstruct the corresponding organizational structure system. Due to the new agricultural science is not only reflected in the emergence of new majors and disciplines, but more of the integration of various disciplines, cross-professional and cross-field majors bring about the corresponding adjustment of the original department and college organizational structure, which means that the organizational structure of these universities and colleges also needs to be rebuilt. For example, the original organizational structures of agriculture and forestry universities and colleges(such as agricultural colleges, plant protection colleges, and animal sciences colleges) may face reorganization and restructuring because they cannot cover new majors and disciplines generated by new agricultural sciences, or consider using dynamic virtual organizations to adapt this need. The third is that the new agricultural science requires all agriculture and forestry universities and colleges to reconstruct their talent training system. Under the background of the construction of new agricultural sciences, the original concept of agricultural and forestry professionals will change. New agricultural sciences talents requires innovative, compound and applied talents, who are multidisciplinary talents. Therefore, it is necessary to increase the cultivation and shaping of new technologies, new situations, humanistic spirit, and moral sentiments in talents training.

\section{DIFFICULTIES IN THE CONSTRUCTION OF NEW AGRICULTURAL SCIENCES IN LOCAL AGRICULTURE AND FORESTRY COLLEGES}

In recent years, local agriculture and forestry universities and colleges across the country have achieved rapid development with the attention and support of local governments at all levels. However, from the perspective of the construction of new agricultural sciences, local agriculture and forestry colleges are facing the following difficulties. First is that the limited on majors and disciplines strength. Among the agriculture and forestry universities and colleges in my country, only the China Agricultural University and Northwest Agriculture \&Forestry University are first-class universities, and the first-class discipline-building universities are only seven universities including Huazhong Agricultural University, Nanjing Agricultural University and Beijing Forestry University, but most of the agriculture and forestry universities and colleges are local agriculture and forestry universities and colleges. Relatively speaking, local agriculture and forestry universities and colleges have weak foundation of education. More importantly, due to the expansion of college enrollment, most local agriculture and forestry universities and colleges set up more disciplines, which are not limited to traditional agriculture and forestry disciplines. Generally, they set up mechanical, construction, water conservancy engineering, mathematics, computer science and humanities and social sciences(such as economics and management and foreign languages), and some local agriculture and forestry universities and colleges also set up arts and sports disciplines and majors. Multiple disciplines and majors play a certain role in attracting students and expanding student numbers, but they disperse the teaching and research strength of disciplines and majors. Thus, problems are likely to occur in the discipline evaluation and talent training. Second, many local agriculture and forestry universities and colleges are located in areas where local financial resources are relatively tight, resulting in limited funds for the construction of new agricultural sciences. Although in recent years the state and governments at all levels have attached great importance to the "issues relating to agriculture, rural areas and rural people" and the financial investment at all levels of agriculture and forestry universities and colleges, there is a relatively large gap compared with ministerial agriculture and forestry universities and colleges. At present, with the expansion of college enrollment, the total 
allocation per student of local finance to agriculture and forestry universities and colleges has increased, but it is far from enough relative to expenditure. Thus, accounting problems are widespread, especially expenditures for key tasks such as the introduction of high-quality talents, teacher training, and discipline construction. Obviously, local agriculture and forestry universities and colleges are under greater financial pressure.

\section{NEW AGRICULTURAL SCIENCE CONSTRUCTION PATH FOR LOCAL AGRICULTURAL AND FORESTRY COLLEGES}

\subsection{Implement the General Requirements of Establishing Morality and Cultivating agricultural talents who "Understand agriculture, Love Agriculture, and Love peasants"}

The orientation of local agriculture and forestry universities and colleges is generally to obey major national development strategies, meet the development requirements of regional agriculture and forestry industries, and cultivate agriculture and forestry professionals who can serve the needs of regional economic and social development. Due to the different positioning of these universities and colleges from the ministry-affiliated universities and colleges and double first-class universities, the destination of students after graduation is also different. Graduates of most local universities and colleges will take root in the grassroots and serve the locality. Therefore, local agriculture and forestry universities and colleges should take the construction of new agricultural sciences as an important starting point for school development, give full play to the synergistic effect of ideological and political education courses and professional courses, and strengthen local agriculture and forestry universities and colleges students' deep understanding of current politics and Xi Jinping Thought on Socialism with Chinese Characteristics for a New Era to guide students to form a down-to-earth, practical, lawabiding, and up-to-earth character in their study and life. All local agriculture and forestry universities and colleges should actively promote thematic and modular teaching in the construction of new agricultural sciences, fully integrate the school's expertise and local characteristics of professional resources and teachers, and integrate rural governance, ecological civilization, and sustainable rural development into the professional courses. During the construction, we will gather the strengths of advantageous and characteristic disciplines and coordinately promote the advantageous and characteristic courses. The talent training program should aim at meeting the future agricultural and rural development, adapt to professional needs as the orientation, and innovate a new model of new agricultural talent training that includes interdisciplinary, professional integration, industry-university integration, and schoolenterprise collaboration. It should also promote that students of agriculture and forestry universities and colleges have a sense of responsibility and mission to serve the future development of rural areas, have high professional ethics and dedication, and have good professional knowledge and professional skills to better serve the development of the times and social needs.

\subsection{Actively Plan the New Agricultural Specialty and Reconstruct the Discipline System of the New Agricultural Specialty}

New agricultural science is the product of the integration of modern science and technology, life sciences, new engineering education, new liberal arts education and traditional agricultural sciences under the background of the new era[3]. The Anji Declaration pointed out that the construction of new agricultural sciences is to transform and upgrade existing agricultural majors with modern science and technology, and to design and set up new agriculturerelated specialty that meet the needs of the development of new industries and new business forms[1]. After long-term development in various agriculture and forestry universities and colleges, traditional agriculture and forestry are generally the advantages and characteristics of local agriculture and forestry universities and colleges, and their long-term accumulation is generally in "agriculture" and "forest". In recent years, information technology represented by big data, cloud computing, and the Internet of Things is profoundly affecting and changing all aspects of people's production and life, and is promoting the transformation of traditional agricultural production and management methods to smart production and management methods[2]. Local agriculture and forestry universities and colleges must actively plan the construction of new agricultural sciences, set up new interdisciplinary majors, and build new agricultural majors or directions that have local and regional characteristics, outstanding advantages, and meet the development needs of national and regional agricultural industries. It must also focus on supporting the effective crossover and organic integration of traditional agronomy, forestry majors, agriculture-related, forestryrelated majors, and non-agricultural and forestry majors, and accelerate the development of multi-disciplinary integration majors, so that the discipline and professional structure of local agriculture and forestry universities and colleges is more in line with the development of contemporary agriculture and rural areas. At the same time, local agriculture and forestry universities and colleges should actively use the Internet, big data, and biotechnology to accelerate the transformation and improvement of the connotation of traditional agriculture and forestry disciplines, and cultivate high-quality compound talents that can meet the requirements of modern agricultural and rural development, so that they can meet the actual demand for talents for current and future agricultural industry development and rural revitalization. The majors that have 
been opened in some agriculture and forestry universities and colleges that do not reflect the school's own teaching level and scientific research level, do not meet the needs of current social and economic development, and have a low employment rate, should be optimized by "transfer, merge, and withdraw". Only by concentrating resources(such as human resources and financial resources) to run superior disciplines and majors, and seizing the opportunity of the construction of new agricultural sciences, can some agriculture and forestry universities and colleges achieve overtaking in curves. However, in the process of the popularization of higher education, many local agriculture and forestry universities and colleges have established many agriculture-related and non-agricultural disciplines. The non-agricultural majors of these local agriculture and forestry universities and colleges are familiar with the related majors of other universities and colleges, and they are facing tremendous competitive pressure in terms of enrollment, employment, and professional evaluation. This requires that local agriculture and forestry colleges must have special characteristics for these agriculture-related and non-agricultural disciplines, and have "misplace development" and differences in professional construction positioning with similar majors of other colleges, by highlighting the organic combination of these majors and agriculture and forestry disciplines, the characteristics of serving the "issues relating to agriculture, rural areas and rural people", and their mutual support and integration with agronomy majors.

\subsection{Optimize Teaching Resources, Improve Practical Teaching Methods and Forms}

Local agriculture and forestry universities and colleges should further seek breakthroughs in practical teaching, adjust and optimize teaching resources to better meet the high requirements for teaching and practice in the cultivation of new agricultural talents. The first is to further reform the current teaching methods and forms, and focus on improving the campus informatization. Students can gain more in classroom teaching through flipped classrooms, blended teaching, and the construction of exploring seminar-oriented classrooms, and the rectification of "easy-A class" and the establishment of "high-value class". The second is to strengthen the training of existing teachers. It is necessary to expand way of thinking, break the geographical and spatial boundaries of the school, and cultivate the teaching, scientific research and innovation and entrepreneurship guidance capabilities of existing teachers more flexibly through cooperation, joint training, online learning, and off-campus base construction. Universities and colleges can train and improve the practical teaching ability of existing teachers by suspending their posts in related companies and co-training with highlevel universities at home and abroad. The third is to focus on the construction of modern teaching resources with the characteristics of the "issues relating to agriculture, rural areas and rural people" and organic integration of multiple disciplines. By improving the construction of campus informatization, these high-quality curriculum resources can be spread online to further enrich the content of students' independent learning.

\subsection{Decouple Organizational Structure, and Reform the Existing Organizational Structure System of Colleges}

The organizational structure of my country's universities, especially the establishment of departments, is generally established on the basis of different disciplines, and there is a strong coupling relationship between disciplines and majors and the establishment of departments. This traditional professional setting mode consolidates disciplinary resources in separate administrative departments, which makes it difficult to support interdisciplinary research projects and hinders the cultivation of interdisciplinary professional talents. Therefore, the educational organization system should be transformed from closed to open, compatible and cooperative, and gradually move towards the direction of decoupling the construction of disciplines and the organization $^{[4]}$. The construction of new agricultural sciences requires the integration of different disciplines, and each professional team must work closely across disciplines and departments, which will challenge the original organizational structure of colleges. All local agriculture and forestry universities and colleges should form a dynamic incorporeal organization focusing on research fields based on information technology. Dynamic virtual organization helps universities to break through the boundary constraints of key resource elements to form core competitiveness and output as soon as possible. For example, the Biomedical Center established by Huazhong Agricultural University is a typical representative of the combination of virtual and reality composed of related departments(such as biology, agriculture, and animal sciences) and related disciplines. The center has full-time administrative positions and authorized strength, and the personnel relationships of professional team members remain in the original college. The members rely on the organization to realize the interaction, integration and sharing of knowledge systems of different disciplines ${ }^{[4]}$ Organizational structure reform is a prerequisite for the development of "new agricultural science" education. In the process of decoupling, different organizational levels should be accurately oriented, define their objectives, value pursuits and key activities, and commit to "establishing an interdisciplinary scientific problem discovery mechanism, and promoting the formation of a more competitive knowledge integration relationship between related disciplines"[5]. Under the guidance of the construction of new agricultural sciences, local agriculture and forestry universities and colleges have established an organizational form for interdisciplinary, inter-academic, and interprofessional talent training, forming a multi-college, multidisciplinary, and multi-specialty integration and dynamic 
development pattern, breaking the existing resource allocation framework, accumulating strength to form the competitiveness of "new agricultural science" construction[6].

\section{CONCLUSION}

Local agricultural and forestry colleges and universities are the pillars of a country to strengthen agriculture and prosper agriculture, and the construction of new agricultural science is a major strategy to revitalize higher agricultural and forestry education. In 2019, Anji consistently put forward the new concept of "four orientations" for new agriculture, new villages, new farmers and new ecological development. And Beidacang action propose the new measures of "eight actions" for deepening the reform of higher agricultural and forestry education. "Beijing Guide" aims to start the new agricultural research and reform practice project, promote the construction with the project, increase the investment with the construction, improve the quality with the investment, and let the new agricultural science take root in Colleges and universities all over the country. Relying on the professional and disciplinary advantages in agriculture and forestry, local agriculture and forestry colleges and universities should expand and strengthen the "new agriculture", run the agriculture specialty well, give full play to the supporting role of science and technology, theory and talents in cultivating new driving forces of agricultural development and upgrading the agricultural industry, and strive to produce more scientific and technological achievements written on the earth and lead the progress of agricultural science and technology and industrial development, so as to cultivate more agricultural science and technology talents who know and love agriculture and contribute to stronger agriculture, more beautiful countryside and richer farmers in China.

\section{REFERENCES}

[1] ANJI Consensus---Declaration on the development of Emerging Agricultural Education in China [J]. China Agricultural Education, 2019 (3): 105-106.

[2] Liu Zhuqing. Historical Evolution, Connotation and Construction Path of "New Agricultural Science" [J].

China Agricultural Education, 2018 (1): 15-21.

[3] Mou Shaoyan, Liu Huanqi, Li Jingsuo. The Connotation, Ideas and Countermeasures of the Construction of New Agricultural Specialty [J]. Higher Agricultural Education, 2020 (1): 7-11

[4] Wang Congyan. The Internal Mechanism and Integrated development path of "New Agricultural
Science" Education[J]. Journal of National Academy of Educational Administration, 2020(01): 30-37.

[5] Huang Chao, Yang Yingjie. From the perspective of Interface Fluctuations---The Main Risks and Governance Countermeasures of University Interdisciplinary Construction[J]. China Higher Education Research, 2017, (5): 55-61.

[6] ]Jiao Xinan, Yu Hongliang, Yang Guoqing, Zhang Yong. Thinking and Practice on the Construction of "New Agricultural Science" in Comprehensive Agricultural Universities[J]. China University Teaching, 2020(05): 22-25. 